\title{
Chromosomal Abnormalities Subdivide Ependymal Tumors into Clinically Relevant Groups
}

\author{
Yuichi Hirose,${ }^{*}$ Kenneth Aldape,${ }^{\dagger}$ Andrew Bollen, ${ }^{\dagger}$ \\ C. David James, ${ }^{\ddagger}$ Daniel Brat, ${ }^{\S}$ \\ Kathleen Lamborn, ${ }^{*}$ Mitchel Berger, ${ }^{*}$ and \\ Burt G. Feuerstein ${ }^{\text {Tाl }}$ \\ From the Departments of Neurological Surgery* and Lab \\ Medicine, ${ }^{\text {Iा }}$ the Division of Neuropathology, the Brain Tumor \\ Research Center and Cancer Genetics Program," University of \\ California, San Francisco, California; the Department of \\ Pathology and Laboratory Medicine, ${ }^{\ddagger}$ Mayo Clinic and \\ Foundation, Rochester, Minnesota; and the Department of \\ Pathology and Laboratory Medicine, ${ }^{\S}$ Emory University, \\ Atlanta, Georgia
}

Ependymoma occurs most frequently within the central nervous system of children and young adults. We determined relative chromosomal copy-number aberrations in 44 ependymomas using comparative genomic hybridization. The study included 24 intracranial and 20 spinal cord tumors from pediatric and adult patients. Frequent chromosomal aberrations in intracranial tumors were gain of $1 q$ and losses on $6 q$, 9, and 13. Gain of 1q and loss on 9 were preferentially associated with histological grade 3 tumors. On the other hand, gain on chromosome 7 was recognized almost exclusively in spinal cord tumors, and was associated with various other chromosomal aberrations including frequent loss of $22 \mathrm{q}$. We conclude that cytogenetic analysis of ependymomas may help to classify these tumors and provide leads concerning their initiation and progression. The relationship of these aberrations to patient outcome needs to be addressed. (Am J Patbol 2001, 158:1137-1143)

Ependymoma is a tumor of neuroepithelial tissue that occurs in both brain and spinal cord, most frequently in children and young adults. Prognosis differs in intracranial and spinal cord tumors. Surgical resection followed by chemotherapy and/or radiotherapy are the most common treatments for intracranial tumors, but the patients frequently relapse. Overall survival and progression-free survival at 5 years are 50 to $60 \%$ and 30 to $50 \%$, respectively. ${ }^{1-3}$ On the contrary, recurrence is rare for ependymomas located in the spinal cord, and gross total resections using surgical microscopy do not need to be treated with adjuvant therapy. ${ }^{4,5}$

A prognostic marker for intracranial ependymomas would be clinically useful, and various factors have been analyzed. Several studies have identified extent of resection as an important variable. ${ }^{1-9}$ Young age at diagnosis is a poor prognostic factor, although a clear explanation for this observation has not been proposed. 1,3,7,10,11 Ependymoma is histologically graded, and high-grade tumors are characterized by the presence of anaplasia; however, it is controversial whether grade is prognostic. ${ }^{1-3,9,12-16}$ Tumors with higher grade have higher MIB-1 labeling index (LI), but this is not well correlated to outcome. $^{10,17-20}$

We hypothesized that a genetic examination of tumor tissue might provide clues to tumor behavior. To date, most genetic studies of ependymomas have been based on karyotyping, ${ }^{21-25}$ polymerase chain reaction (PCR)based microsatellite analysis, ${ }^{26-31}$ and NF2 sequencing. ${ }^{31,32}$ Karyotyping depends on in vitro culture of surgically resected tumor tissue, and therefore may not represent the whole population of tumor cells. Microsatellite analysis provides only limited coverage over the whole genome. Comparative genomic hybridization $(\mathrm{CGH})$ screens the whole genome of all cells in a tumor in a single experiment at a resolution of several megabases. Recently, a CGH study of pediatric ependymomas was published. ${ }^{33}$ Our study adds information concerning genetic differences between intracranial and spinal cord ependymomas and between pediatric and adult cases. We determined chromosomal copy number aberrations (CNAs) of 44 ependymomas including intracranial and spinal cord tumors in pediatric and adult cases using $\mathrm{CGH}$. We believe that classification of ependymomas based on their cytogenetic characteristics may help to identify a useful prognostic marker and provide clues to understanding the development of these tumors.

\section{Materials and Methods}

\section{Tissue Samples}

Samples of ependymomas from 35 patients were obtained from the Brain Tumor Research Center Tissue

\footnotetext{
Supported in part by the National Institutes of Health (NCI) grants CA13525, CA64898, and CA82103; Cancer Center core grant CA82103; and funds from the National Brain Tumor Foundation and the Farber Foundation.

Accepted for publication December 4, 2000

Address reprint requests to Burt G. Feuerstein, Cancer Genetics Program, Box 0808, UCSF, San Francisco, CA 94143-0808. E-mail: feuer@cc.ucsf.edu.
} 
Bank at the University of California, San Francisco, six samples were from the Mayo Clinic, and three samples were from Emory University. All samples were taken from different patients. Pathological examination was performed by neuropathologists (University of California, San Francisco, cases by $K A$ and $A B$, and Mayo and Emory cases by DB) according to World Health Organization criteria. ${ }^{34}$

\section{Preparation and Labeling of DNA}

In 26 cases, test DNA was extracted from frozen tissue of ependymomas using a standard protocol with incubation in sodium dodecyl sulfate and proteinase $\mathrm{K}$ followed by phenol/chloroform extraction. ${ }^{35}$ DNA concentration was measured fluorometrically. The DNA was labeled with fluorescein isothiocyanate (FITC) by nick translation using DNA polymerase I. Reference DNA was extracted from leukocytes of normal donors and labeled with Texas Red-dUTP in the same manner. If the amount of tumor tissue was small, the DNA was amplified and labeled by degenerate oligonucleotide primer-polymerase chain reaction (DOP-PCR) ${ }^{36}$ using FITC-dUTP (as noted below). We confirmed that DOP-PCR products from our method produced faithful CGH profiles (Hirose Y, Aldape K, Takahashi M, Berger M, Feuerstein BG, manuscript submitted).

In 17 cases, DNA was extracted from formalin-fixed and paraffin-embedded tissue section (5- $\mu \mathrm{m}$ thick) and amplified by DOP-PCR. Tissue was deparaffinized and incubated in $1 \times$ PCR Buffer (Roche, Indianapolis, IN) with $0.5 \%$ Tween-20 (Sigma Chemical Co., St. Louis, MO) and 0.4 mg/ml proteinase K (Life Technologies, Inc., Rockville, MD) for 3 days at $55^{\circ} \mathrm{C}$. Proteinase $\mathrm{K}$ was added twice a day ( $1 \mu \mathrm{g}$ per $2.5 \mu \mathrm{l}$ of sample volume). After 3 days, proteinase $\mathrm{K}$ was inactivated by heating 10 to 15 minutes at $95^{\circ} \mathrm{C}$, and an aliquot was subjected to DOP-PCR.

DOP-PCR amplification was performed in two phases with DNA extracts prepared as above. In the first phase (low stringency reaction), $1 \mu$ l of sample was added to the buffer containing dNTPs (dATP, dCTP, dGTP, and dTTP; Roche), DOP primer (5'-CCGACTCGAGNNNNNNATGTGG-3', where $N=A, C, G$, or T) and 1' Sequenase reaction buffer (Amersham, Cleveland, $\mathrm{OH}$ ). The reaction was performed with five cycles at $30^{\circ} \mathrm{C}$ for 5 minutes, $37^{\circ} \mathrm{C}$ for 2 minutes, and $96^{\circ} \mathrm{C}$ for 2 minutes, adding Sequenase (Amersham) at each $30^{\circ} \mathrm{C}$ step. The first phase product was subjected to the second phase reaction where Taq polymerase (Roche) was used. Thermal cycle conditions were: $95^{\circ} \mathrm{C}$ for 5 minutes, 35 cycles at $94^{\circ} \mathrm{C}$ for 1 minute, $56^{\circ} \mathrm{C}$ for 1 minute, and $72^{\circ} \mathrm{C}$ for 2 minutes, followed by final extension at $72^{\circ} \mathrm{C}$ for 5 minutes.

DNA was labeled with another DOP-PCR reaction using digoxigenin-11-dUTP (Roche). Thermal cycle conditions were as follows: $95^{\circ} \mathrm{C}$ for 10 minutes, 25 cycles at $94^{\circ} \mathrm{C}$ for 70 seconds, $56^{\circ} \mathrm{C}$ for 70 seconds, and $72^{\circ} \mathrm{C}$ for 3 minutes, followed by final extension at $72^{\circ} \mathrm{C}$ for 10 minutes.

Reference DNA was amplified from 50 ng of normal male DNA and labeled as described above except that FITC-dUTP (Du Pont Inc., Wilmington, DE) was used instead of digoxigenin-dUTP.

\section{CGH}

Metaphase spreads were prepared from normal human male peripheral-blood lymphocytes stimulated with phytohemagglutinin. CGH was performed according to the procedure described by Mohapatra and colleagues. ${ }^{37}$ The labeled DNAs were hybridized to target lymphocyte metaphase spreads. After washing, the metaphases were incubated with rhodamine-conjugated anti-digoxigenin antibody, washed, and counterstained with 4,6diamino-2-phenylinodole in antifade solution. Red, green, and blue images were acquired with a Quantitative image processing system (QUIPS), and the ratios of fluorescence intensity along the chromosomes were quantitated. ${ }^{38}$ A relative gain was scored when the mean test: reference ratio was $>1.2$ and relative loss was scored when the mean green: red ratio was $<0.8 .{ }^{39} \mathrm{CNAs}$ were not scored at or near the centromeres. Amplifications were scored only when visual inspection revealed a bright and discrete signal confined to a subchromosomal region.

\section{Statistical Analysis}

The total numbers of CNAs for intracranial and spinal cord tumors were compared by a nonparametric MannWhitney test. We examined whether specific CNAs in intracranial tumors were associated with histological grade, tumor location, or type of the disease (primary or recurrent) using Fisher's exact test. Fisher's exact test was also used to test for associations among CNAs. For these analyses we considered only those CNAs that occurred in $20 \%$ or more of the total intracranial sample.

\section{Results}

Our study population consisted of 24 intracranial and 20 spinal cord tumors. Because a cursory examination of the results showed that these comprised two separate genetic groups, we analyzed the two groups separately. CGH profiles were successfully obtained from each of the 44 samples that we investigated including DNAs extracted from frozen tissue and those extracted and amplified from paraffin-embedded sections. Two cases (intracranial cases no. 10 and no. 22 in Table 1) were examined by both nick translation and DOP-PCR, and the resulting CGH profiles were similar (Figure 1; intracranial case no. 10).

Table 1 and Figure 2 are a summary of the intracranial tumors. Ten cases were diagnosed as ependymoma (World Health Organization grade 2), and 13 cases were anaplastic ependymomas (World Health Organization grade 3). Fourteen tumors were infratentorial and nine were supratentorial. CNAs were recognized in 19 (79\%) of 24 tumors. CNAs frequently recognized were gains on $1 \mathrm{q}$ (7 cases); and losses on 6q (6 cases), 9p (9 cases), and $9 q$ (6 cases). There were no distinguishable amplifications. The mean value of total CNAs was 2.5 per case. Correlations of these frequent CNAs to tumor histology or location are shown in Table 2. Gain on 1q occurred more frequently in grade 3 tumors, but the correlation was not 
Table 1. Chromosomal Aberrations in Intracranial Ependymomas

\begin{tabular}{|c|c|c|c|c|c|c|c|c|}
\hline Case & $\begin{array}{l}\text { Age } \\
\text { (yrs) }\end{array}$ & Sex & Disease & Location & $\begin{array}{l}\text { Grade } \\
(\mathrm{WHO})\end{array}$ & CNAs & Gain & Loss \\
\hline 1 & 0.8 & M & Primary & I & 3 & 0 & & \\
\hline 2 & 0.8 & $\mathrm{~F}$ & Primary & I & 3 & 1 & & $9 p$ \\
\hline 3 & 2 & M & Primary & S & 2 & 1 & & $9 p$ \\
\hline 4 & 2 & $\mathrm{~F}$ & Recurrent & S & 3 & 1 & & $22 q$ \\
\hline 5 & 2 & $\mathrm{~F}$ & Recurrent & I & 2 & 0 & & \\
\hline 6 & 2 & $\mathrm{~F}$ & Recurrent & S & 3 & 0 & & \\
\hline 7 & 3 & M & Recurrent & I & 3 & 2 & & $9 p, 22 q$ \\
\hline 8 & 5 & $\mathrm{~F}$ & Primary & I & 2 & 2 & $1 q$ & $10 q$ \\
\hline 9 & 7 & $M$ & Recurrent & i & 3 & 2 & $1 q$ & 9 \\
\hline 10 & 9 & $\mathrm{M}$ & Recurrent & S & 3 & 2 & $1 \mathrm{q}$ & 9 \\
\hline 11 & 12 & $\mathrm{~F}$ & Primary & I & 2 & 4 & & $6,10,13 q, 16$ \\
\hline 12 & 12 & M & Recurrent & I & 2 & 6 & 1q, 5pter-q21, 7q21-ter, 18 & 1pter-36.1, $6 \mathrm{q}$ \\
\hline 13 & 13 & M & Primary & I & 3 & 3 & & 6q23-ter, 12pter-q23, 13q12-21.2 \\
\hline 14 & 18 & M & Primary & S & 3 & 1 & & $13 q$ \\
\hline 15 & 20 & $\mathrm{~F}$ & Recurrent & S & 3 & 6 & $8,20 q$ & $3 p, 9,22 q, x$ \\
\hline 16 & 25 & M & Primary & I & 2 & 0 & & \\
\hline 17 & 25 & $\mathrm{M}$ & Primary & S & 3 & 3 & $1 \mathrm{q}$ & $9,16 q$ \\
\hline 18 & 27 & $\mathrm{~F}$ & Primary & I & 3 & 8 & $1 q, 5,7,9$ & $2,3,6, x$ \\
\hline 19 & 31 & M & Primary & I & 2 & 4 & $12,15 q$ & $6, x$ \\
\hline 20 & 33 & $\mathrm{~F}$ & Recurrent & $S$ & 3 & 3 & $1 \mathrm{q}, \mathrm{x}$ & 9 \\
\hline 21 & 42 & $\mathrm{M}$ & Primary & I & 2 & 5 & $5,9,12,15 q, 19$ & \\
\hline 22 & 59 & M & Recurrent & S & 3 & 5 & & $5 q, 9,11 p, 13, Y$ \\
\hline 23 & 66 & $\mathrm{M}$ & Primary & I & 2 & 1 & & 6 \\
\hline 24 & 84 & $\mathrm{~F}$ & Primary & S & 2 & 0 & & \\
\hline
\end{tabular}

I, infratentorial; S, supratentorial; CNAs, copy number aberrations.

statistically significant. Loss of $6 q$ and loss of 9 (either $p$ or $q$ arm) were mutually exclusive. Cases with loss of $6 q$ were all infratentorial tumors. Cases with loss of $9 p$ but without loss of $9 q$ were all intracranial and 3 years of age or younger. On the other hand, losses that included 9q were seen in six intracranial cases 7 years of age or older. This aberration correlated with histological grade 3 $(P=0.024)$ and supratentorial location $(P=0.050)$.

\section{A}

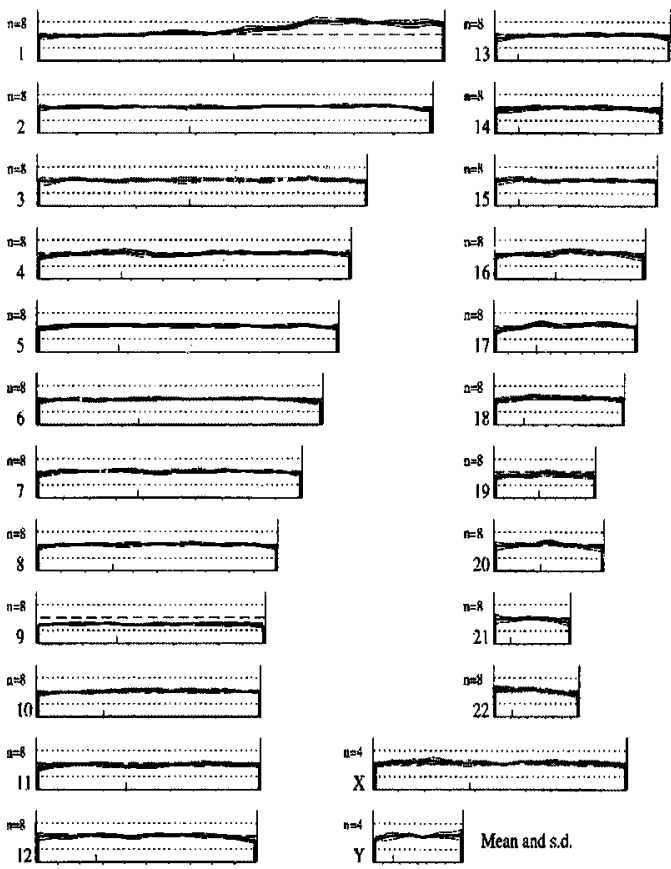

B

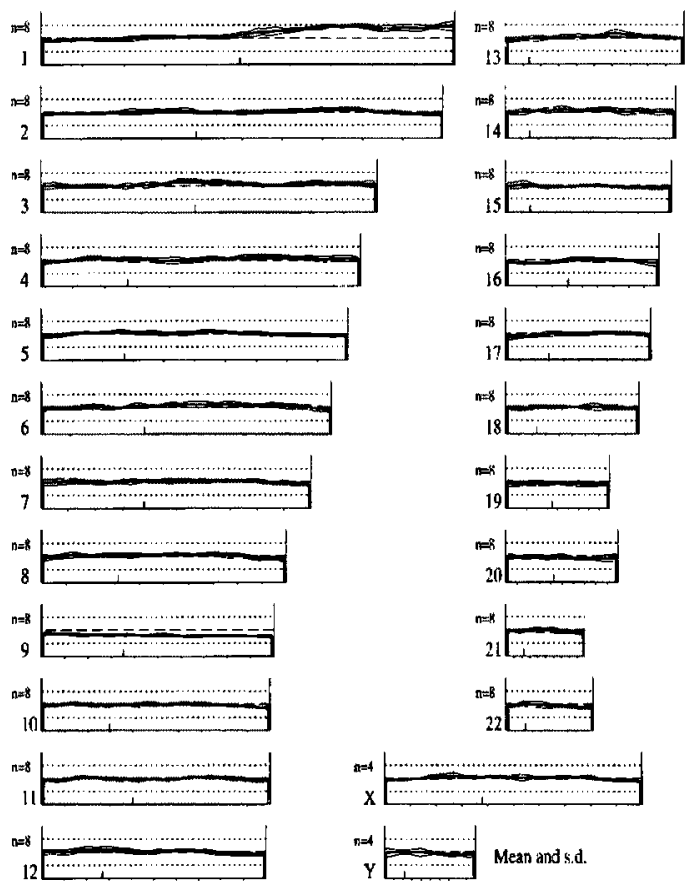

Figure 1. Ratio profile from a case labeled by both nick translation (A) and DOP-PCR (B) (intracranial case no. 10, 9-year-old male, anaplastic ependymoma) The $x$ axis represents the position along the chromosome ( $\mathrm{p}$ arm to the left and $\mathrm{q}$ arm to the right). The centromeres are marked by a crosshatch on the $x$ axis The $y$ axis represents normalized test/reference fluorescence intensity ratios. Both profiles show an increase in relative DNA copy number on 1q and a decrease on 9 . 


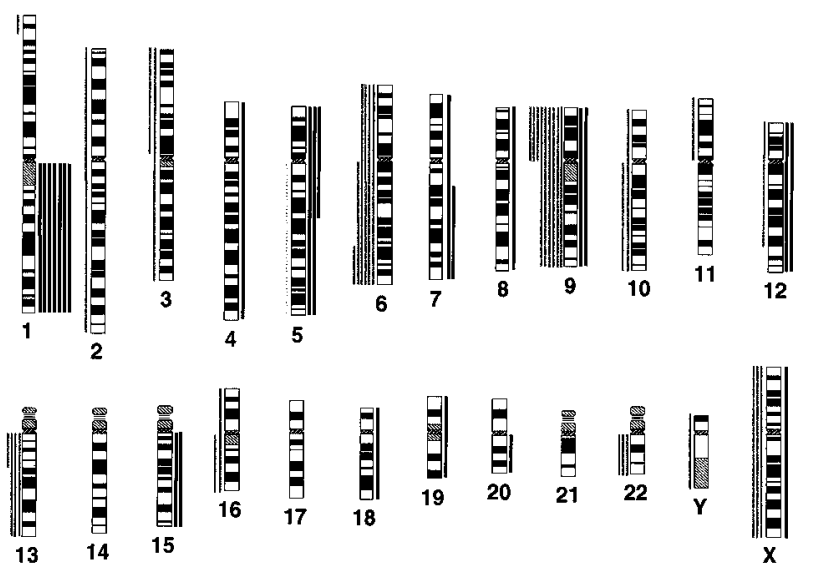

Figure 2. Summary of CNAs in 23 intracranial ependymomas. Lines to the left of each chromosome idiogram show regions of reduced relative DNA copy number, and lines to the right show regions of increased relative DNA copy number. Each line represents a CNA found in one tumor. CNAs frequently recognized in $\mathrm{CGH}$ for intracranial ependymomas were gain of 1q (seven cases); loss of 6 (six cases), 9p (nine cases), and 13 (four cases). There were no distinguishable amplifications.

There was no relationship between CNAs and whether disease was primary or recurrent.

Associations among these aberrations were examined (Table 3), and only association between gain on $1 \mathrm{q}$ and loss of $9 q$ was significant $(P=0.048)$.

Table 4 and Figure 3 show a summary of CGH results from spinal cord tumors. All cases were primary disease. Fourteen cases were intramedullary (conventional) ependymoma (World Health Organization grade 2), and six cases were myxopapillary ependymomas. CNAs were recognized in all 20 cases. Nearly all spinal cord ependymomas had gain on chromosome 7 (19 of 20 cases). Other CNAs frequently recognized were gains on chromosome 2 (5 cases), 5 ( 6 cases), 9 (14 cases), 12 (8 cases), 15 (6 cases), 18 (5 cases), 20q (5 cases), and X (11 cases); and losses on $13 q$ ( 4 cases) and $22 q$ (11 cases). All aberrations involved the whole arm or the whole chromosome. There were no distinguishable amplifications.

Association among these aberrations were tested, and gain on chromosome 12 was significantly associated with gains on $15(P=0.018)$ and $X(P=0.005)$, and loss on $22 \mathrm{q}(P=0.028)$. The number of total CNAs in spinal cord cases was 6.2 per case; this was significantly greater than the mean number of CNAs in intracranial cases $(P<$ 0.001). Losses of chromosome 1 and 10 were recognized only in the youngest (ie, 10 years of age) spinal cord cases of myxopapillary type; loss of 22 q was not recognized in myxopapillary tumors.
Table 3. Association among Frequent Aberrations in Intracranial Ependymomas

\begin{tabular}{ccc}
\hline Combination & Observed cases & $P$ value \\
\hline$+1 q /-6 q$ & $2 / 24(8.2 \%)$ & $>0.999$ \\
$+1 q /-9 p$ & $4 / 24(16.7 \%)$ & 0.36 \\
$+1 q /-9 q$ & $4 / 24(16.7 \%)$ & 0.038 \\
$-6 q /-9 p$ & $0 / 24(0.0 \%)$ & 0.052 \\
$-6 q /-9 q$ & $0 / 24(0.0 \%)$ & 0.28 \\
\hline
\end{tabular}

\section{Discussion}

Previous studies suggested the genetic differences between intracranial and spinal cord ependymomas, however, they are focused on specific genetic locus. ${ }^{31,32}$ Our results show clear and more remarkable cytogenetic differences between tumors that occurred in intracranial and spinal cord ependymomas. First, there were far more CNAs in spinal cord (median, 6; range, 2 to 10) than in intracranial (median, 2; range, 0 to 6) tumors. This was especially evident in the gains. Tumors of the spinal cord had a median of 4 gains (range, 0 to 8 ) and intracranial tumors had a median of 0 gains (range, 0 to 5). Secondly, the CNAs in these two groups were different. 19 of 20 spinal cord tumors featured gain on chromosome 7 . Other frequent CNAs seen in $20 \%$ or more of the spinal cord cases included gain of 2 ( 5 cases), 5 (6 case), 9 (14 cases), 12 (8 cases), 15 (6 cases), 18 (5 cases), 20q (5 cases), and X (11 cases); and loss of $13 q$ ( 4 cases) and $22 q$ (11 cases); these CNAs were far less frequent in the intracranial cases. On the other hand, intracranial cases had frequent gains on 1q (7 cases) and losses on 9 (8 cases); these CNAs were nearly absent in the spinal cord tumors. This suggests that intracranial and spinal cord ependymomas progress along substantially different pathways although they comprise one histological entity. It is well known that intracranial tumors frequently relapse ${ }^{1-8,10}$ and that spinal cord tumors rarely relapse after gross total resection. ${ }^{4,5}$ Our data suggest that the differences in clinical behavior are related to cytogenetic profiles. Studies that compare genetic aberrations of ependymal tumors and outcome should be performed to confirm this hypothesis.

The frequency of whole chromosome 7 gain is an important difference between spinal cord and intracranial ependymomas. Only one spinal cord tumor did not have a whole gain on chromosome 7 . This tumor was unusual because it had the smallest number of gains and the smallest number of CNAs among spinal cord tumors (a situation reminiscent of intracranial tumors) furthermore, it was the only spinal cord tumor with loss on $9 \mathrm{q}$, a region

Table 2. Correlation of Frequent Aberrations in Intracranial Ependymomas to Tumor Grade or Location

\begin{tabular}{|c|c|c|c|c|c|c|}
\hline \multirow{2}{*}{$\begin{array}{c}\text { Chromosomal } \\
\text { aberration }\end{array}$} & \multicolumn{3}{|c|}{ Histology } & \multicolumn{3}{|c|}{ Location } \\
\hline & Grade 2 & Grade 3 & $P$ value & Supratentorial & Infratentorial & $P$ value \\
\hline$+1 q$ & 2/10 (20.0\%) & $5 / 14(35.7 \%)$ & 0.65 & $3 / 10(30.0 \%)$ & 4/14 (28.6\%) & $>0.999$ \\
\hline$-6 q$ & $3 / 10(30.0 \%)$ & $3 / 14(21.4 \%)$ & 0.19 & $0 / 10(0 \%)$ & $6 / 14(42.9 \%)$ & 0.024 \\
\hline$-9 p$ & $1 / 10(10.0 \%)$ & $8 / 14(57.2 \%)$ & 0.033 & $6 / 10(50.0 \%)$ & $3 / 14(21.4 \%)$ & 0.092 \\
\hline$-9 q$ & $0 / 10(0 \%)$ & $6 / 14(42.9 \%)$ & 0.024 & $5 / 10(50.0 \%)$ & $1 / 14(7.2 \%)$ & 0.05 \\
\hline
\end{tabular}


Table 4. Chromosomal Aberrations in Spinal Cord Ependymomas*

\begin{tabular}{|c|c|c|c|c|c|c|c|}
\hline Case & $\begin{array}{c}\text { Age } \\
\text { (years) }\end{array}$ & Sex & Location & Histology & CNAs & Gain & Loss \\
\hline 1 & 10 & $\mathrm{~F}$ & Cauda equina & MP & 7 & $3,7,9,11$ & $1,2,10$ \\
\hline 2 & 10 & $M$ & Cauda equina & MP & 4 & $7,9 q, 14 q, 20$ & $1,2,10$ \\
\hline 3 & 10 & $\mathrm{~F}$ & L5 & $\mathrm{E}$ & 6 & $5,7,8,9,18,21$ & \\
\hline 4 & 12 & M & Cauda equina & $\mathrm{MP}$ & 7 & $7,9,20$ & $2,4,6,12$ \\
\hline 5 & 15 & M & Cauda equina & MP & 7 & $5,7,9,16,18,20$ & 4 \\
\hline 6 & 17 & M & C1-C5 & $\mathrm{E}$ & 4 & $7,12, x$ & $22 q$ \\
\hline 7 & 17 & M & $\mathrm{C} 7$ & $E$ & 7 & $4,7,9,12,15 q, X$ & $22 q$ \\
\hline 8 & 18 & M & Cauda equina & MP & 7 & $4,7,9,18,21 q, X$ & $15 q$ \\
\hline 9 & 18 & M & Cauda equina & MP & 3 & $7,9 q, 20 q$ & $6 q$ \\
\hline 10 & 23 & M & C3 & $E$ & 2 & & $9 q, 14$ \\
\hline 11 & 25 & $\mathrm{~F}$ & T12-L1 & $\mathrm{E}$ & 6 & 5,7 & $1 p, 13 q, 14 q, 22 q$ \\
\hline 12 & 29 & $\mathrm{~F}$ & L2-L5 & $\mathrm{E}$ & 7 & $2,5,7,9 q, 17$ & $13 q, 22 q$ \\
\hline 13 & 38 & $\mathrm{~F}$ & C3-C7 & $\mathrm{E}$ & 3 & 7,9 & $22 q$ \\
\hline 14 & 39 & M & $\mathrm{C} 5$ & E & 4 & $7,12, x$ & $22 q$ \\
\hline 15 & 40 & $\mathrm{~F}$ & $\mathrm{C} 2-\mathrm{C} 5$ & $\mathrm{E}$ & 6 & $2,7,9,12, x$ & $22 q$ \\
\hline 16 & 43 & M & C3-T1 & $\mathrm{E}$ & 9 & $2,5,7,8,9,12,15 q, x$ & $22 q$ \\
\hline 17 & 44 & $\mathrm{~F}$ & C & $\mathrm{E}$ & 8 & $7,9,15 q, 18,20, X$ & $13,22 q$ \\
\hline 18 & 46 & M & C7-T1 & $\mathrm{E}$ & 4 & $7,12,15 q$ & $22 q$ \\
\hline 19 & 49 & $\mathrm{~F}$ & C5-T2 & $\mathrm{E}$ & 9 & $2,7,9,10,12,15 q, 18, X$ & 4 \\
\hline 20 & 51 & M & C4-T2 & $\mathrm{E}$ & 10 & $2,5,7,12,15 q, x$ & $11,13,14,22 q$ \\
\hline
\end{tabular}

E, ependymoma (grade 2); MP, myxopapillary ependymoma; CNAs, copy number aberrations

${ }^{*}$ All spinal cord cases were primary disease.

lost frequently in the intracranial group. There was only one intracranial tumor with whole gain of 7 . Interestingly, this tumor had the largest number of CNAs among intracranial tumors (reminiscent of the large numbers of CNAs found in the spinal cord group). Gains on chromosome 7 are the most frequent aberration in grade 2 to 4 astrocytic tumors (Hirose Y, Aldape K, Takahashi M, Chang S, Larson D, Lamborn K, Berger M, Feuerstein BG, submitted data) ${ }^{40-42}$ and mark radiation resistance (Kunwar S, Mohapatra G, Bollen A, Lamborn K, Prados M, Feuerstein BG, submitted data). ${ }^{43}$ The aberrations in spinal cord ependymomas, however, differ from those in grade 2 and 3 astrocytomas. Aberrations in spinal cord ependymomas cover whole arms of chromosomes or whole chromosomes, whereas aberrations in grade 2 and 3 astrocytomas often target smaller chromosomal regions ((Hirose Y, Aldape K,

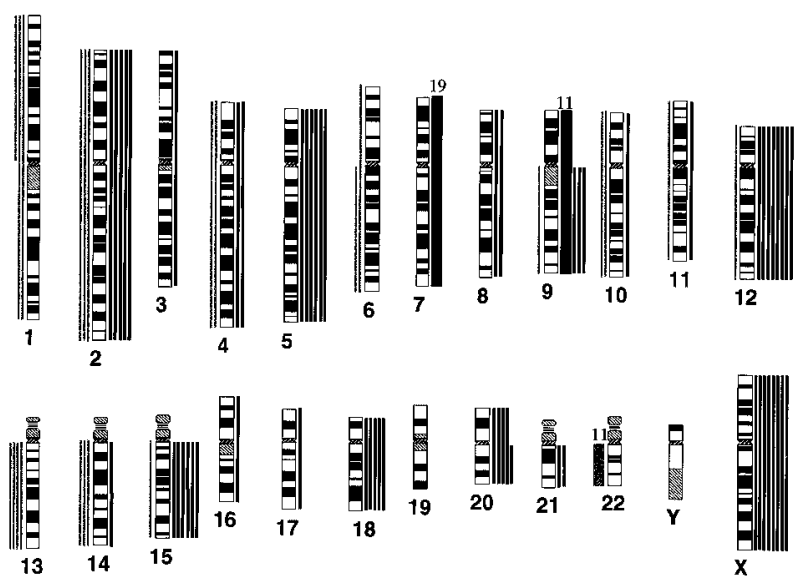

Figure 3. Summary of CNAs in 20 spinal cord ependymomas. Most cases showed gain of 7 . Other frequently recognized CNAs were gain of 2 (five cases), 5 (six cases), 9 (14 cases), 12 (eight cases), 15 (six cases), 18 (five cases), 20q (five cases), and X (11 cases); loss of 2 (three cases) and 22q. The thick lines reflect the number of tumors (shown above the lines) with similar aberrations. There were no distinguishable amplifications.
Takahashi M, Chang S, Larson D, Lamborn K, Berger M, Feuerstein BG, submitted data). A similar situation occurs in neuroblastomas, where lower grade tumors have aberrations involving whole chromosomes or chromosomal arms, but higher grade tumors have aberrations that involve smaller chromosomal regions. ${ }^{44}$

It is believed that young patients with intracranial disease ( $<3$ to 5 years of age) have a poorer outcome than older patients. ${ }^{1,3,7,9,10}$ Cases 3 years of age or younger in our study had less CNAs (mean, 0.7 per case; range, 0 to 2) compared to older cases (mean, 3.3 per case; range, 0 to 8 ). This suggests that the clinical behavior of ependymomas may not simply be associated with the number of CNAs per case. Instead, the specific cytogenetic aberrations we see in the tumors from younger patients may be directly related to their biology. Furthermore, the only aberrations found in tumors from patients $\leq 3$ years old were 1) loss on 9p (this lesion occurred only in young patients) and 2) loss on $22 \mathrm{q}$ (this lesion occurred in two of seven young patients and in 1 of 17 older patients). And three tumors from this younger group had no cytogenetic aberrations by $\mathrm{CGH}$.

Thus, the cytogenetic aberrations we found in the 17 intracranial tumors from patients $>3$ years of age were different from those found in younger patients. These tumors had frequent gain of $1 \mathrm{q}$ (7cases) and losses on 6 (six cases), 9 (six cases), 13 (four cases), and X (three cases). Our pilot data suggest that cytogenetic aberrations differ in younger and older patients. These differences may underlie age-related differences in outcome.

The relationship of intracranial ependymoma grade to outcome is controversial. ${ }^{1-3,9,10,13-15,20,21}$ Nonetheless, there were indications that gain of $1 \mathrm{q}$ and loss of 9 and 13 were preferentially associated with histological grade 3 (five of seven cases, six of six cases, and three of four cases, respectively) among intracranial tumors. Because $R b$ is located on $13 q^{45,46}$ and $\ln k 4 A$ is located on $9 p,{ }^{47}$ 
these results suggest that the cyclin D/CDK4 pathway ${ }^{48}$ is disrupted more frequently in grade 3 than in grade 2 intracranial ependymomas. Alterations at other members of this pathway such as cyclin $D$ have not been described. On the other hand, although mutation of p53 is rare in ependymomas, ${ }^{49,50}$ the p53 pathway might be altered because Arf, whose product stabilizes p53, is also located on 9p.51,52 Our results are consistent with the idea that grade is associated with particular CNAs. If difficulties in grading underlie an inability to correlate grade and outcome in intracranial ependymoma, we might find that CNAs correlating with higher grade might be indicators for outcome. Further clinical studies and assays of relevant genes are needed to explore these issues.

Other interesting findings in intracranial tumors include associations of loss on $6 q$ with infratentorial location and loss on $9 q$ with supratentorial location (Table 2). It is possible that selection pressures in these two regions differ, resulting in different progression pathways. Such differences might affect the biology of the tumor and its response to therapy.

Loss of whole 9 was associated with gain on $1 \mathrm{q}$ (four of six cases), but was never seen in six cases with loss on $6 q$. Furthermore, loss of whole 9 and $6 q$ were preferentially seen in supratentorial and infratentorial tumors, respectively. This suggests that there are subgroups within intracranial ependymomas characterized by chromosomal aberrations.

Our results also suggest that intramedullary spinal cord ependymomas and myxopapillary ependymomas are different genetic subgroups although both share the common genetic characteristic of chromosome 7 gain. Loss on 22q (11 tumors), gains of $15 q$ (five tumors), and 12 (seven tumors) did not occur in myxopapillary tumors, whereas losses of chromosome 1 (two tumors), 2 (three tumors), and 10 (two tumors) occurred solely in the myxopapillary group. Loss on X (11 tumors) occurred in only one myxopapillary tumor (Table 4). It was interesting that two infratentorial intracranial tumors with gain on 12 also had gain on $15 q$ and vice versa (Table 1). Neither of these tumors had the gain on 7 so characteristic of spinal cord tumors however. These associations suggest that a specific genetic pathway operates in myxopapillary tumors. There is also a suggestion that gains on 12 and $15 q$ are involved in a pathway that acts both in the body of the spinal cord and in the posterior fossa. Although myxopapillary tumors grow slowly, ${ }^{18}$ they do have a greater potential for dissemination through the central canal than other spinal ependymomas. ${ }^{16}$ Thus, different CNAs in these two groups of spinal ependymomas may underlie differences in their clinical behavior.

Because neurofibromatosis type 2 (NF2) predisposes toward development of multiple central and peripheral nervous system tumors including ependymoma ${ }^{53}$ and because the NF2 gene is located on chromosome arm $22 \mathrm{q},{ }^{54,55}$ studies focusing on the status of this gene in ependymomas have been performed. ${ }^{26,29-32,56}$ These studies suggest that deletion or mutation of NF2 is more common in spinal cord tumors than in pediatric intracranial tumors. Our data suggest that chromosome 22 is frequently lost in spinal cord ependymoma, and this is consistent with the idea that alterations of NF2 are frequently involved in their development.

In conclusion, our pilot data suggest that intracranial and spinal cord ependymomas are different genetic diseases and comprise different subgroups within one histological entity. Furthermore, we have evidence that both intracranial and spinal cord ependymomas can be further subdivided. Categorization of these tumors by cytogenetic aberrations may help establish a classification system that predicts patient outcome. A study with larger number of cases and outcome data are needed to determine the clinical significance of the groups we have identified.

\section{References}

1. Pollack IF, Gerszten PC, Martinez AJ, Lo KH, Shultz B, Albright AL, Janosky J, Deutsch M: Intracranial ependymomas of childhood: Iongterm outcome and prognostic factors. Neurosurgery 1995, 37:655667

2. Robertson PL, Zeltzer PM, Boyett JM, Rorke LB, Allen JC, Geyer JR Stanley P, Li H, Albright AL, McGuire-Cullen P, Finlay JL, Stevens Jr KR, Milstein JM, Packer RJ, Wisoff J, the Children's Cancer Group: Survival and prognostic factors following radiation therapy and chemotherapy for ependymomas in children: a report of the Children's Cancer Group. J Neurosurg 1998, 88: 695-703

3. Horn B, Heideman R, Geyer R, Pollack I, Packer R, Goldwein J, Tomita T, Schomberg P, Ater J, Luchtman-Jose L, Rivlin K, Lamborn K, Prados M, Bollen A, Berger M, Dahl G, McNeil E, Patterson K, Shaw $D$, Kubalik M, Russo C: A multi-institutional retrospective study of intracranial ependymoma in children: identification of risk factors. J Pediatr Hematol Oncol 1999, 21:203-211

4. McLaughlin MP, Marcus Jr RB, Buatti JM, McCollough WM, Mickle JP, Kedar A, Maria BL, Million RR: Ependymoma: results, prognostic factors and treatment recommendations. Int $\mathrm{J}$ Radiat Oncol Biol Phys 1998, 40:845-850

5. Asazuma T, Toyama Y, Suzuki N, Fujimura Y, Hirabayashi K: Ependymomas of the spinal cord and cauda equina: an analysis of 26 cases and a review of the literature. Spinal Cord 1999, 37:753-759

6. Jayawickreme DP, Hayward RD, Harkness WFJ: Intracranial ependymomas in childhood: a report of 24 cases followed for 5 years. Childs Nerv Syst 1995, 11:409-413

7. Duffner PK, Krischer JP, Sanford RA, Horowitz ME, Burger PC, Cohen ME, Friedman HS, Kun LE, the Pediatric Oncology group: Prognostic factors in infants and very young children with intracranial ependymomas. Pediatr Neurosurg 1998, 28:215-222

8. Donahue B, Steinfeld A: Intracranial ependymomas in the adult patient: successful treatment with surgery and radiotherapy. J Neurooncol 1998, 37:131-133

9. Palma L, Celli P, Mariottini A, Zalaffi A, Schettini G: The importance of surgery in supratentorial ependymomas: long-term survival in a series of 23 cases. Childs Nerv Syst 2000, 16:170-175

10. Ritter AM, Hess KR, McLendon RE, Langford LA: Ependymomas: MIB-1 proliferation index and survival. J Neurooncol 1998, 40:51-57

11. Sala F, Talacchi A, Mazza C, Prisco R, Ghimenton C, Bricolo A: Prognostic factors in childhood intracranial ependymomas: the role of age and tumor location. Pediatr Neurosurg 1998, 28:135-142

12. Ross GW, Rubinstein LJ: Lack of histopathological correlation of malignant ependymomas with postoperative survival. J Neurosurg 1989, 70:31-36

13. Schiffer D, Chiò A, Cravioto H, Giordana MT, Migheli A, Soffietti R, Vigliani MC: Ependymoma: internal correlations among pathologic signs and the anaplastic variant. Neurosurgery 1991, 29:206-210

14. Ernestus RI, Schröder R, Stützer H, Klug N: Prognostic relevance of localization and grading in intracranial ependymomas of childhood. Childs Nerv Syst 1996, 12:522-526

15. Rezai AR, Woo HH, Lee M, Cohen H, Zagzag D, Epstein FJ: Disseminated ependymomas of the central nervous system. J Neurosurg 1996, 85:618-624

16. Schwartz TH, Kim S, Glick RS, Bagiella E, Bakmaceda C, Fetell MR, 
Stein BM, Sisti MB, Bruce JN: Supratentorial ependymomas in adult patients. Neurosurgery 1999, 44:721-731

17. Prayson RA: Myxopapillary ependymomas: a clinicopathologic study of 14 cases including MIB-1 and p53 immunoreactivity. Mod Pathol 1997, 10:304-310

18. Prayson RA: Cyclin D1 and MIB-1 immunohistochemistry in ependymomas. Am Clin Pathol 1998, 110:629-634

19. Rushing EJ, Yashima K, Brown DF, White III CL, Shay JW, Risser RC, Gazdar AF: Expression of telomerase RNA component correlates with the MIB-1 proliferation index in ependymomas. J Neuropathol Exp Neurol 1997, 56:1142-1146

20. Rushing EJ, Brown DF, Hladik CL, Risser RC, Mickey BE, White III CL: Correlation of bcl-2, p53, and MIB-1 expression with ependymoma grade subtype. Mod Pathol 1998, 11:464-470

21. Thiel G, Losanowa T, Kintzel D, Nisch G, Martin H, Vorpahl K. Witkowski R: Karyotypes in 90 human gliomas. Cancer Genet Cytogenet 1992, 58:109-120

22. Griffin CA, Long PP, Carson BS, Brem H: Chromosome abnormalities in low-grade central nervous system tumors. Cancer Genet Cytogenet 1992, 60:67-73

23. Rogatto SR, Casartelli C, Raindho CA, Barbieri-Neto J: Chromosomes in the genesis and progression of ependymomas. Cancer Genet Cytogenet 1993, 69:146-152

24. Bhattacharjee MB, Armstrong DD, Vogel H, Cooley LD: Cytogenetic analysis of 120 primary pediatric brain tumors and literature review. Cancer Genet Cytogenet 1997, 97:39-53

25. Vagner-Capodano AM, Zattara-Cannoni H, Gambarelli D, FigarellaBranger D, Lena G, Dufour H, Grisoli F, Choux M: Cytogenetic study of 33 ependymomas. Cancer Genet Cytogenet 1999, 115:96-99

26. Ransom DT, Ritland SR, Kimmel DW, Moertel CA, Dahl RJ, Scheithauer BW, Kelly PJ, Jenkins RB: Cytogenetic and loss of heterozygosity studies in ependymomas, pilocytic astrocytomas, and oligodendrogliomas. Genes Chromosom Cancer 1992, 5:348-356

27. Bijlsma EK, Voesten AMJ, Bijleveld EH, Troost D, Westerveld A, Mérel $\mathrm{P}$, Thomas G, Hulsebos TJM: Molecular analysis of genetic changes in ependymomas. Genes Chromosom Cancer 1995, 13:272-277

28. von Haken MS, White EC, Daneshvar-Shyesther L, Sih S, Choi E, Karla R, Cogen PH: Molecular genetic analysis of chromosome arm $17 p$ and chromosome arm 22q DNA sequences in sporadic pediatric ependymomas. Genes Chromosom Cancer 1996, 17:37-44

29. Kramer DL, Pariter AH, Rorke LB, Sutton LN, Biegel JA: Molecular cytogenetic studies of pediatric ependymomas. J Neurooncol 1998, 37:25-33

30. Hulsebos TJM, Oskam NT, Bijleveld EH, Westerveld A, Hermsen MA, van den Ouweland AMW, Hamel BC, Tijssen CC: Evidence for an ependymoma tumor suppressor gene in chromosome region 22pter22q11.2. Br J Cancer 1999, 81:1150-1154

31. Rubio MP, Correa KM, Ramesh V, MacCollin MM, Jacoby LB, von Deimling A, Gusella JF, Louis DN: Analysis of the neurofibromatosis 2 gene in human ependymomas and astrocytomas. Cancer Res 1994, 54:45-47

32. Ebert C, von Haken M, Meyer-Puttilitz B, Wiestler OD, Reifenberger G, Pietsch T, von Deimling A: Molecular genetic analysis of ependymal tumors. NF2 mutations and chromosome 22q loss occur preferentially in intramedullary spinal ependymomas. Am J Pathol 1999, 155:627-632

33. Reardon DA, Entrekin RE, Sublett J, Ragsdale S, Li H, Boyett J, Kepner JL, Look AT: Chromosome arm 6q loss is the most common recurrent autosomal alteration detected in primary pediatric ependymoma. Genes Chromosom Cancer 1999, 24:230-237

34. Kleihues P, Burger PC, Sheithauer BW: Histological Typing of Tumors of the Central Nervous System, ed 2. Berlin, Springer-Verlag, 1993, pp 5-30

35. Sambrook J, Fritsch EF, Maniatis T: Molecular Cloning: A Laboratory Manual, ed 1. New York, Cold Spring Harbor Laboratory Press, 1992

36. Cheung VG, Nelson SF: Whole genome amplification using a degenerative oligonucleotide primer allows hundreds of genotypes to be performed on less than one nanogram of genomic DNA. Proc Natl Acad Sci USA 1996, 93:14676-14679

37. Mohapatra G, Kim DH, Feuerstein BG: Detection of multiple gains and losses of genetic material in ten glioma cell lines by comparative genomic hybridization. Genes Chromosom Cancer 1995, 13:86-93

38. Piper J, Rutovitz D, Sudar D, Kalloniemi A, Kalloniemi OP, Waldman FM, Gray JW, Pinkel D: Computer image analysis of comparative genomic hybridization. Cytometry 1995, 19:10-26
39. Kim DH, Mohapatra G, Bollen A, Waldman FM, Feuerstein BG: Chromosomal abnormalities in glioblastoma multiforme tumors and glioma cell lines detected by comparative genomic hybridization. Int J Cancer 1995, 60:812-819

40. Schröck E, Blume C, Meffert MC, du Manoir S, Bersch W, Kiessling M, Lozanowa T, Thiel G, Witkowski R, Ried T, Cremer T: Recurrent gain of chromosome arm $7 \mathrm{q}$ in low-grade astrocytic tumors studied by comparative genomic hybridization. Genes Chromosom Cancer 1996, 15:199-205

41. Mohapatra G, Bollen AW, Kim DH, Lamborn K, Moore DH, Prados MD, Feuerstein BG: Genetic analysis of glioblastoma multiforme provides evidence for subgroups within the grade. Genes Chromosom Cancer 1998, 21:195-206

42. Nishizaki T, Ozaki S, Harada K, Ito H, Arai H, Beppu T, Sasaki K: Investigation of genetic alterations associated with the grade of astrocytic tumor by comparative genomic hybridization. Genes Chromosom Cancer 1998, 21:340-346

43. Huhn SL, Mohapatra G, Bollen A, Lamborn K, Prados MD, Feuerstein BG: Chromosomal abnormalities in glioblastoma multiforme by comparative genomic hybridization: correlation with radiation treatment outcome. Clin Cancer Res 1999, 5:1435-1443

44. Plantaz D, Mohapatra G, Matthay KK, Pellarin M, Seeger RC, Feuerstein BG: Gain of chromosome 17 is the most frequent abnormality detected in neuroblastoma by comparative genomic hybridization. Am J Pathol 1997, 50:81-89

45. Lee WH, Bookstein R, Hong F, Young LJ, Shew JY, Lee EY: Human retinoblastoma susceptibility gene: cloning, identification, and sequence. Science 1987, 235:1394-1399

46. Friend SH, Bernards R, Rogelj S, Weinberg RA, Rapaport JM, Albert DM, Dryja TP: A human DNA segment with properties of the gene that predisposes to retinoblastoma and osteosarcoma. Nature 1986, 323: 643-646

47. Kamb A, Shattuck-Eidens D, Eeles R, Liu Q, Gruis NA, Ding W Hussey C, Tran T, Miki Y, Weaver-Feldhaus J, McClure M, Aitken JF, Anderson DE, Bergman W, Frants R, Goldgar DE, Green A, MacLennan R, Martin NG, Meyer LJ, Youl P, Zone JJ, Skolnick MH, CannonAlbright LA: Analysis of the p16 gene (CDKN2) as a candidate for the chromosome 9p melanoma susceptibility locus. Nat Genet 1994, 8:23-26

48. Serrano M, Hannon GJ, Beach D: A new regulatory motif in cell-cycle control causing specific inhibition of cyclin D/CDK4. Nature 1993, 366:704-707

49. Nozaki M, Tada M, Matsumoto R, Sawamura Y, Abe H, Iggo RD: Rare occurrence of inactivating p53 gene mutations in primary non-astrocytic tumors of the central nervous system: reappraisal by yeast functional assay. Acta Neuropathol 1998, 95:291-296

50. Fink KL, Rushing EJ, Schold Jr SC, Nisen PD: Infrequency of p53 gene mutations in ependymomas. J Neurooncol 1996, 27:111-115

51. Pomerantz J, Schreiber-Agus N, Liegeois NJ, Siverman A, Alland L, Chin L, Potes J, Orlow I, Lee HW, Cordon-Cardo CC, DePinho RA: The INK4a tumor suppressor gene product, p19ARF, interacts with MDM2 and neutralizes MDM2's inhibition of p53. Cell 1998, 92:713-723

52. Zhang $Y$, Xiong $Y$, Yarbrough WG: ARF promotes MDM2 degradation and stabilizes p53: ARF-INK4a locus deletion impairs both the pRb and the p53 tumor suppressor pathways. Cell 1998, 92:725-734

53. Martuza RL, Eldridge R: Neurofibromatosis 2 (bilateral acoustic neurinomatosis). N Engl J Med 1988, 318:684-688

54. Trofatter JA, MacCollin MM, Ruttner JL, Murrell JR, Duyao MP, Parry DM, Eldridge R, Kley N, Menon AG, Pulaski K, Haase VH, Ambrose CM, Munroe D, Bove C, Haines JL, Martuza RL, MacDonald ME, Seizinger BR, Short MP, Buckler AJ, Gusella JF: A novel moesin-, ezrin-, radixin-like gene is a candidate for the neurofibromatosis 2 tumor suppressor. Cell 1993, 72:791-800

55. Rouleau GA, Merel P, Lutchman M, Sanson M, Zucman J, Marineau C, Hoang-Zuang K, Demczuk S, Desmaze C, Plougastel B, Pulst SM, Lenoir G, Bijlsma E, Fashold R, Dumanski J, de Jong P, Parry D, Eldridge R, Aurias A, Delattre O, Thomas G: Alteration in a new gene encoding a putative membrane-organizing protein causes neurofibromatosis type 2. Nature 1993, 363:515-521

56. Slavc I, MacCollin MM, Dunn M, Jones S, Sutton L, Gusella JF, Biege JA: Exon scanning for mutations of the NF2 gene in pediatric ependymomas, rhabdoid tumors and meningiomas. Int J Cancer 1995, 64: 243-247 